\title{
Productivity and quality of Anthurium andreanum influenced with growing conditions and fertilizers
}

\author{
Chhungpuii Khawlhring* \\ Department of Horticulture, Aromatic and Medicinal Plants, Mizoram University, Tanhril- \\ 796004 (Mizoram), India \\ Gaurang D. Patel \\ Polytechnic in Horticulture, ASPEE College of Horticulture and Forestry, Navsari \\ Agricultural University, Paria-396145 (Gujarat), India \\ F. Lalnunmawia \\ Department of Botany, Mizoram University, Tanhril-796004 (Mizoram), India
}

${ }^{*}$ Corresponding author. E-mail: puii.kh@gmail.com

\begin{abstract}
An experiment was carried out to study the productivity and flower quality of Anthurium andreanum cv. Evita cultivated in shade house (75\% shade net) and under natural forest trees at Herbal garden, School of Earth Sciences \& Natural Resources, Management, Mizoram University, Tanhril, Mizoram. There were six different nutrient sources as $F_{0}$ control (no additional nutrient source); $F_{1}$ - NPK (19:19:19) @ 25 g/pot/year; $F_{2}$ - Biofertilizers (azospirillum and phosphotika) each @ 3 g/pot/year; $F_{3}$ - Cattle manure @ 1.0 kg/ pot/year; $F_{4^{-}}$Pig manure @1.0 kg/pot/year and $F_{5^{-}}$Poultry manure @ 0.5 kg/pot/year were applied in three equal splits. The experiment was laid out in Randomized Block design with factorial concept comprising in three replications. All vegetative and flowering parameters differ significantly at 0.05 level, and were observed better under Shade house ( $75 \%$ shade net) condition. Number of suckers per pot (4.77), number of leaves (23.73), leaf area $\left(257.79 \mathrm{~cm}^{2}\right)$, flower stalk length $(41.68 \mathrm{~cm})$, flower stalk diameter $(5.95 \mathrm{~mm})$, spadix length $(60.77 \mathrm{~cm})$, spadix diameter $(10.02 \mathrm{~mm})$, spathe area $\left(103.25 \mathrm{~cm}^{2}\right)$, vase life (19.67days) and number of flower per plant (3.57) were found maximum in $\mathrm{F}_{1}-\mathrm{NPK}$ (19:19:19) @ 25 g/pot/year. Hence Anthurium andreanum cv. Evita planted in cocopeat, charcoal and vermicompost in the proportion of 6.5:1:1 placed under shade house (75\% shade net) and fertilized with NPK (19:19:19) @ 25 g/pot/year can enhance growth and flowering characters.
\end{abstract}

Keywords: Anthurium, Flower quality, Natural forest trees, Potting nutrients, Shade house

\section{INTRODUCTION}

The anthurium is a unique ornamental plant that stands out among most of the tropical cultivated flowers for its exquisiteness, durability and long vase-life. Anthurium belongs to the family Araceae, and is an evergreen, tropical herbaceous plant. It is a shade plant and therefore, have to be protected against too much direct light, radiation and wind (van der Leeden, 2001). It is also an interesting crop for agroforestry under dense canopies. In high rainfall areas, floriculture with anthurium under trees is highly profitable and provides a good permanent groundcover which effectively controls erosion (Anonymous, 1991).

Anthurium attract vast majority of growers for its massive effect, elegance and variety of colors, and consequently need to standardize the growing techniques (Islam et al., 2013). According to Chang et al., (2010), organic fertilizers such as

\section{Article Info}

DOI:10.31018/jans.v11i2.2024 Received: February 19, 2019

Revised: March 20, 2019

Accepted: April 1, 2019

\section{How to Cite}

Khawlhring, C. et al. (2019). Productivity and quality of Anthurium andreanum influenced with growing conditions and fertilizers. Journal of Applied and Natural Science,11 (2): 240244 https://doi.org/10.31018/ jans.v11i2.2024 
beds laid out inside shade house, and also under natural forest trees. A soilless media was prepared by mixing cocopeat, charcoal and vermicompost in the proportion of 6.5:1:1 filled plastic pot $(25 \mathrm{~cm}$ width and $21 \mathrm{~cm}$ height with 10.3 litre volume) used for planting of tissue culture plantlets of anthurium cV. Evita (AVO Anthurium Vogels, Holland). The nutrients from the different sources were applied thrice in a year at four month interval.

Two kinds of growing conditions, one was of inside shade house of $75 \%$ shade net and Tree shade (plants cultivated under the shade of natural forest trees). The other treatment was that for nutrient sources. The different sources of nutrient were applied $F_{0}$ - control (no additional nutrient source); $F_{1}$ - NPK (19:19:19) @ 25 g/pot/year; $F_{2}$ Biofertilizers (azospirillum and phosphotika) each @ 3 g/pot/year; $F_{3}$ - Cattle manure @ 1.0 kg/pot/ year; $F_{4^{-}}$Pig manure @1.0 kg/pot/year and $F_{5^{-}}$ Poultry manure@ 0.5 kg/pot/year.

The experimental design being adopted may be considered as Randomized Block design with factorial concept comprising in three replications. Each treatment represents an individual 12 pots with a single treatment each and 3 randomly selected pots were taken for recording the observations.

Flowers produced were harvested and their number recorded regularly, and their sum was obtained and analysis was taken for a year, and was recorded as the number of flowers per plant per year of that plot. A representative sample flower from each treatment was taken as one time observation, and subjected for several analysis like leaf area, stalk length and diameter; spadix length and diameter; spathe area and vase life (days) of the cut flower while No. of leaf and No. of suckers per plant were recorded at the end of an experiment.

Representative sample of leaf and spathe were measured in a leaf area meter (Systronics leaf area meter 211). A relationship between linear measurements and spathe area was established (Dufour and Guerin, 2003). The equation was:

Area $\left(\mathrm{cm}^{2}\right)=0.94 \times$ length $(\mathrm{cm}) \times$ breadth $(\mathrm{cm})$

...Eq.1

With a coefficients of determination $R^{2}=0.96$. The total area, calculated with the equation was analyzed.

To examine the relationship between each of the flower quality parameters, correlation between each of the parameters, like between stalk length and stalk diameter, spadix length and spathe area etc, are calculated and presented in table form (Table 2).

\section{RESULTS AND DISCUSSION}

Vegetative parameters: In current investigation, it was observed that number of suckers per plant, number of leaves, leaf area $\left(\mathrm{cm}^{2}\right)$ of Anthurium were significantly influenced at 0.05 level by growing conditions (Table-1). Anthurium placed under Shade house ( $75 \%$ shade net) condition observed better significantly at 0.05 level in case of all vegetative parameters. In case of different potting nutrients, treatment $F_{1}$ - NPK (19:19:19) @ $25 \mathrm{~g} / \mathrm{pot} /$ year was found superior in all vegetative parameters. Number of suckers per plant and leaf area was found statistically at par with treatment $\mathrm{F}_{5^{-}}$ Poultry manure @ 0.5 kg/pot/year while number of leaves per plant were on the same bar of $F_{5} F_{4}$ and $F_{2}$. Uikey et al. (2015) from their study on pea (Pisum sativum), concluded that combination of organic manure, bio-fertilizer and inorganic fertilizers were important to improve the growth and yield attributing characters. Sangeetha et al., (2012) also opined that combined application of chemical fertilizers and organic manures have synergistic effects in periwinkle (Catharanthus roseus L.) production.

Number of flowers: Flower production varied significantly at 0.05 level under shade house and tree shade conditions (Table 1). The average number of flowers produced per plant per year during experiment under shade house was 3.54, which was much higher than those under tree shade (1.72). The effects of environmental conditions such as cultivation conditions and seasons are apparent in the number of flowers produced by anthurium plants. Dufour and Guerin (2003) also discussed that the number of flowers produced may decrease during certain months such as February, April and November in their experiment with anthurium cultivation, but these variations are not related to temperature. Chang et al. (2012) showed that regardless of nutrient treatment, the climate in the spring and summer (April-October) of their study was beneficial for $A$ growth and flower yield as a result of the higher air temperature and PAR than in the fall and winter (OctoberApril).

Anthurium fertilized with NPK (19:19:19) @ 25 g/ pot/year treatment resulted in the highest number of flowers per plant per year with 3.57 , this was followed by poultry manure treatment (2.83) and pig manure treatment (2.60), however the lowest flower number (2.03) was noted under control treatment. Canover and Henny (1995) observed that proper fertilizer dose and source to plant can enhance anthurium flower yield, and for this they suggest use of $900-1200 \mathrm{lb} N / \mathrm{A} / \mathrm{yr}$ from a 1-11ratio fertilizer such as a liquid $20-20-20$ or slow release 14-14-14 Osmocote. Uikey et al. (2015) from their study on Pisum sativum, concluded that combination of organic and inorganic fertilizers were important to quality flower production. According to Mohanty et al. (2015) application of organic inputs in combination with chemical fertilizers $(50 \%$ vermicompost $+50 \%$ NPK) was found better option than application of organic manure or 
Khawlhring, C. et al. / J. Appl. \& Nat. Sci. 11(2): 240- 244 (2019)

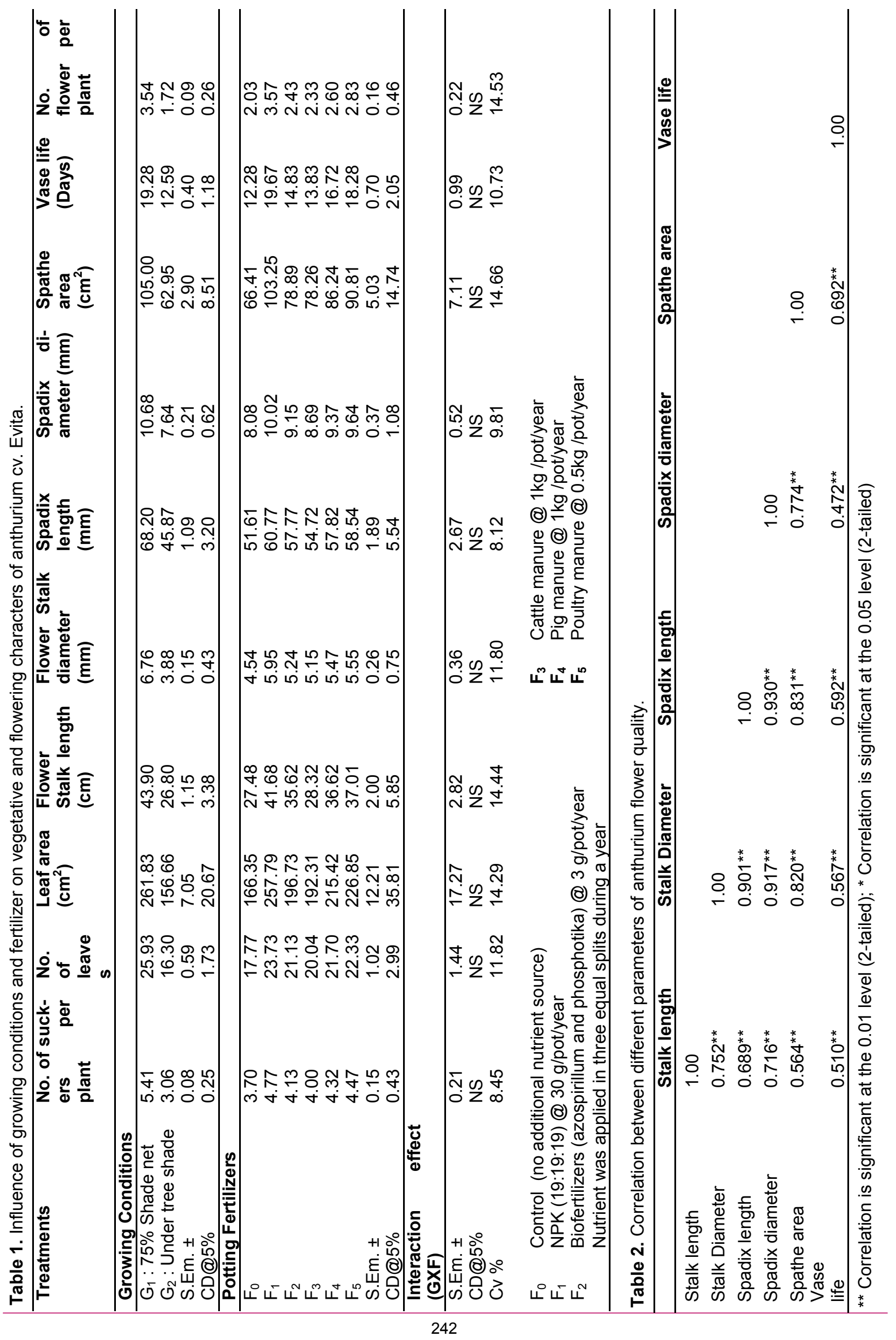


biofertilizer alone for the growth and yield of onion (Allium cepai L.)

Flower quality parameters: Observation on different parameters of flower quality was made. Detail morphological characters and vase life under shade conditions and various treatments are presented in table-1. Results reveal that longest stalk length $(43.90 \mathrm{~cm})$, stalk diameter $(6.76 \mathrm{~cm})$, Spadix length $(68.20 \mathrm{~mm})$ and spadix diameter $(10.68 \mathrm{~mm})$ were obtained under shade house while the least results were noted under tree shade. Moreover, larger spathe area $\left(105.00 \mathrm{~cm}^{2}\right)$ was obtained under shade house, which was much higher than those under tree shade $(62.95$ $\mathrm{cm}^{2}$ ). Agasimani et al. (2011) also observed difference in spathe length and spathe breadth with the effect of difference in growing conditions for $A$. andreanum flowers. Flower quality of $A$. andreanum is also affected by environmental factors such as light and temperature (Nirmala et al., 1999) and Hatibarua et al. (2005).

The longest stalk length $(41.68 \mathrm{~cm})$, stalk diameter $(5.95 \mathrm{~cm})$, Spadix length $(60.77 \mathrm{~mm})$ and spadix diameter $(10.02 \mathrm{~mm})$ were significantly higher with NPK treatment compared to other treatments, which was statistically at par with poultry manure, pig manure and bio-fertilizers treatments. In case of spathe area, treatment $F_{1}$ - NPK (19:19:19) @ $25 \mathrm{~g} /$ pot/year have largest spathe area $\left(103.25 \mathrm{~cm}^{2}\right)$ which was on the same bar of $F_{5}$, while the lowest spathe area was observed in control $\left(66.41 \mathrm{~cm}^{2}\right)$. Supply of NPK may have enhanced the nitrogen and carbohydrate metabolism resulting in greater stalk lengths (Ahmed, 2006) and other quality characters too.

The flowers were kept in vase solution containing pure water and were observed for their vase life. Observations reveal that flowers obtained from under tree shade have a comparatively shorter vase life compared to flowers from plants grown under shade house. Flowers grown under shade house condition retain fresh longer with significantly maximum vase life (19.28 days) as compared to those grown under forest tree shade (12.59 days). This might be due to favourable surrounding environment that leads to better plant performance which is responsible for longer vase life. Similar trend was observed by Femina et al. (2006) with diversified polyhouse structures.

Anthurium fertilized with NPK had maximum vase life (19.67 days) which was statistically on the same bar with poultry manure treatment $(18.28$ days). However, the least vase life (12.28 days) was noted in control treatment. According to Waheeduzzama et al., (2006), the addition of NPK or organic manures result in slow and steady release of nutrient and moisture to the plant that assist in maintenance of turgor in the leaf and flower which favourably extended the vase life of $A$. andreanum flower.
The correlation table (Table 2) revealed that there was significant effect between different parameters of flower quality observed during the experiment. There was a positive correlation between stalk length with stalk diameter (0.752), spadix length (0.689), spadix diameter $(0.716)$, spathe area $(0.564)$, and vase life $(0.510)$, and these correlations are highly significant $(P=0.01)$. Also stalk diameter have positive correlation with spadix length (0.901), spadix diameter (0.917), spathe area $(0.820)$ and vase life $(0.567)$; spadix length again has positive correlation with spadix diameter $(0.930)$ and spathe area (0.831) and vase life (0.592); spadix diameter has a significant positive correlation with spathe area (0.774) and vase life $(0.472)$ at 0.01 level of significance. There is a positive correlation between vase life and spathe area (0.692) at 0.01 level of significance.

\section{Conclusion}

Tissue culture plantlets of $A$. andreanum cv. Evita planted in cocopeat, charcoal and vermicompost in the proportion of 6.5:1:1 filled plastic pot placed under shade house $(75 \%$ shade net) and fertilized with NPK (19:19:19)@ 25 g/pot/year can enhance growth and flowering characters.

\section{REFERENCES}

1. Agasimani, A.D., Harish, D.K., Imamsaheb, S.J. and Patil, V.S. (2011). Anthurium Varieties Performance in Rainy and Winter Seasons under Greenhouse. Res. Journ. of Agri. Sc.,2(2): 337-339.

2. Ahmed, Z. (2006). Standardization of nutrient requirement in Anthurium andreanum Lind. M.Sc thesis, AAU, Jorhat.

3. Anonymous, (1991). Agroforestry development: Tropical Forestry Action Programme - Dominica: Report on Agroforestry / Crops. FAO corporate document repository.

4. Canover, C.A. and Henny, R.J. (1995). Effect of Nitrogen and Potassium fertilization ratios on growth and flowering of three anthurium hybrids. University of Florida, CFREC-Apopka Research Report RH-952

5. Chang, K.H., Wu, R.Y., Chuang, K.C., Hsieh, T.F., and Chung, R.S.(2010). Effects of chemical and organic fertilizers on the growth, flower quality and nutrient uptake of Anthurium andreanum, cultivated for cut flower production. Scientia Horticulturae, 125: 434-441. doi:10.1016/j.scienta.2010.04.011

6. Chang, K.H., Wu, R.Y., Chang, G.P., Hsieh, T.F. and Chung, R.S.(2012). Effects of Nitrogen Concentration on Growth and Nutrient Uptake of Anthurium andraeanum Lind. Cultivated in Coir under Different Seasonal Conditions. HortScience, 47 (4): 515-521.

7. Dufour, L. and Guerin, V. (2003). Growth development features and flower production of Anthurium andreanum Lind. in tropical conditions. Scientia Hort. 98: 25-35. https://doi.org/10.1016/S0304-4238(02) 00196-6

8. Femina, P.K., Valsalakumari, and Rajeevan, P.K. (2006). Performance of anthurium (Anthurium andre- 
anum Lind.) cultivars under different systems of growing in humid tropical plains. Journal of Ornamental Horticulture, 9(4): 274-277.

9. Hatibarua, P., Das, S., Machahary, R. and Paswan, L. (2005). Comparison of different shade levels on flower production of Anthurium andreanum. International Conf. on Plasticulture and Precision FarmingBook of Abstracts, pp: 69

10.Islam, M.S., Mehraj, H., Roni, M.Z.K., Shahrin, S. and Jamal uddin, A.F.M. (2013). Varietal study of anthurium (Anthurium andraeanum) as a cut flower in Bangladesh. Journal of Bangladesh Academy of Sciences, 37 (1): 103-107

11.Mohanty, A., Behera, P. and Harichandan, S. (2015). Effect of nutrient management on the growth and productivity of onion. Agriculture Science Digest., 35 (3): 241-243

12.Nirmala, K.S., Singh, F. and Chandravadana, M.V.
(1999). Anthocyanins of Anthurium andreanum Lind. - Presence of an unknown pigment. Journal of $A p$ plied Horticulture, 1(1): 29-31.

13.Sangeetha, M., Paramasivam, P. and Jegadeeswari, D. (2012). Response of Catharanthus roseus L. to organic and inorganic fertilization. Agric. Science Digest., 32 (4): 329-331.

14.Uikey, V., Verma, H. and Nawange, D. (2015). Influence of organic, chemical and biofertilizer on growth and yield of pea. Agric. Science Digest., 35 (3): 237 240. DOI: $10.5958 / 0976-0547.2015 .00055 .5$

15.Van der Leeden, M. (2001). Culture tips for anthurium. Crop cultivation - GPN.

16.Waheeduzzama, M., Jawaharlal, M., Arulmozhiyan, R. and Indhumathi, K. (2006). Effect of integrated nutrient management practices on flower quality and vase life of Anthurium andreanum cv. Meringue. Journal of Ornamental Horticulture, 9(2): 142-144. 